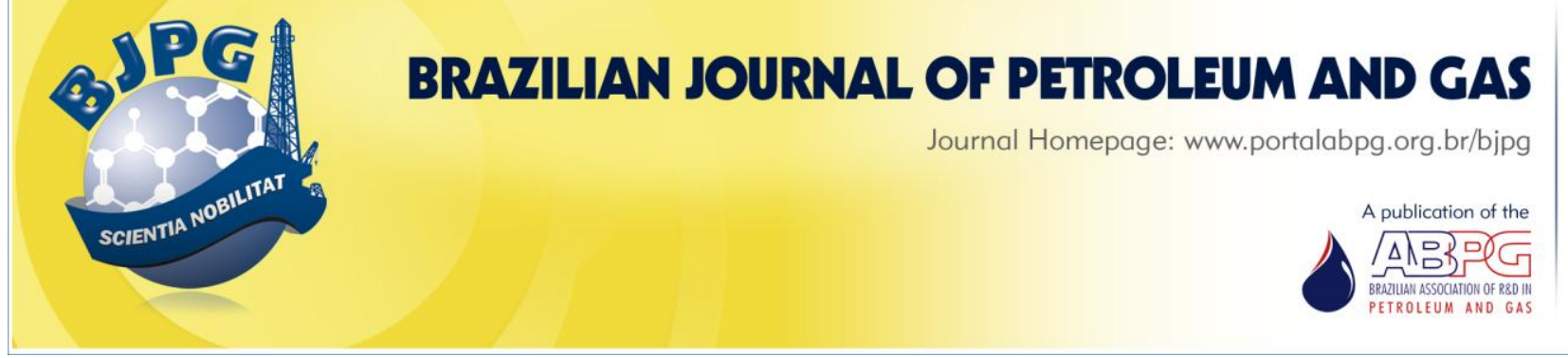

\title{
ORGANOPHILIC CLAY FOR OIL/WATER SEPARATION PROCESS BY FINITE BATH TESTS
}

\author{
${ }^{a}$ Mota, M. F.; ${ }^{a}$ Silva, J. A.; ${ }^{a}$ Queiroz, M. B.; ${ }^{\text {a }}$ Laborde, H. M.; ${ }^{\text {a }}$ Rodrigues, M. G. F. ${ }^{1}$ \\ ${ }^{\text {a }}$ Academic Unit of Chemical Engineering, Federal University of Campina Grande
}

\section{ABSTRACT}

This study examines the inclusion of a quaternary ammonium salt, an alkyl-dimethyl-benzyl ammonium chloride (Dodigen), on a green clay to evaluate its performance as an organophilic adsorbent in the oil/water separation process. The samples were characterized by X-Ray Diffraction, Differential Thermal and Thermogravimetric Analyses, Infrared Spectroscopy, Cation Exchange Capacity, Adsorption Capacity and the Foster Swelling test. The results indicated that the quaternary ammonium salts were intercalated between the layers of clay. A $2^{2}$-factorial design was conducted with three central points in finite bath tests to determine the rate and capacity of oil removal by the organophilic clays. Values as high as $94.54 \%$ of removal efficiency and $37.57 \mathrm{mg} / \mathrm{g}$ of removal capacity were reached in the assays, thus indicating that the use of organophilic clay has great potential in the oil/water separation process.

\section{KEYWORDS}

organophilic clay; swelling; oil/water separation process; emulsion

\footnotetext{
${ }^{1}$ To whom all correspondence should be addressed.

Address: Academic Unit of Chemical Engineering, Federal University of Campina Grande, Av. Aprígio Veloso, 882 - Bodocongó Campina Grande - Paraíba - Brazil

CEP: 58429-970 | Telephone: (55) 83 2101-1488, (55) 83 2101-1115 | Fax: (55) 83 2101-1488 |e-mail: meiry@deq.ufcg.edu.br doi:10.5419/bjpg2011-0011
} 


\section{INTRODUCTION}

Removal of chemical contaminants from water continues to be a central problem in environmental remediation. In general, there are a limited number of sorbent materials used to extract chemical species from water, notably activated carbon (Bandosz, 2006) and, to a lesser extent, molecular sieves (Flanigen et al., 1978). Activated carbon works effectively in a number of applications, but suffers from a lack of reversibility (Sheintuch and Meytal, 1999), uncertainty when determining whether its full capacity has been reached, and inability to remove highly polar organic species (Sutherland et al., 2004). As a result, new waterpurification technologies have been proposed towards the development of alternative adsorption methods, such as reverse osmosis, bioremediation, and reactive chemistry. However, there still exists the potential for new methods of adsorption-based remediation using advanced materials (Ahmadun et al., 2009; Shannon and Semiat, 2008).

With the increasing demand for oil and its derivatives, the production of oil-water emulsions starts to be a major problem. This undesirable effluent needs treatment before its final disposal, because of legal requirements for emission to the environment (CONAMA, 2007) and technical requirements for injection into oil wells.

There are currently many applications of organoclays, which can be used as precursors to nanocomposites or as sorbents in pollution prevention and environmental remediation, for example, in the treatment of spills, wastewater and hazardous waste landfills.

In recent years, organoclays have attracted great interest due to their academic and industrial importance (Bergaya and Lagaly, 2001; Ray and Okamoto, 2003). Organoclays are an important type of modified clay material, which can be synthesized by introducing cationic surfactants such as quaternary ammonium compounds (QACs) into the interlayer space through ion exchange (Soule and Burns, 2001; Chaiko, 2002). As a result of the hydration of inorganic cations on exchange sites, the clay mineral surface becomes hydrophilic, thereby rendering natural clays ineffective sorbents for adsorbing organic compounds (Kim et al., 2003). The treatment of clays with cationic surfactants makes them hydrophobic, increasing their adsorption capacity for organic pollutants characterized by low water solubility or polarity (Boyd et al., 1988a; Boyd et al., 1988b; Xu et al., 1997).

Studies of interactions between clay minerals and organic compounds have been presented by Lagaly (1984) and Yariv and Cross (2002), among others. The countless clay-organic complexes of great industrial importance are the organoclays prepared from smectites and quaternary ammonium salts.

The synthesis of organoclays is based on the reaction mechanisms that take place when clay minerals interact with organic compounds. Displacement reactions occur when water molecules in the interlayer space of smectites and vermiculites are displaced by polar molecules. Neutral organic compounds can form complexes with the interlayer cations. In the case of smectites the adsorption of neutral molecules is driven by various chemical interactions: hydrogen bonds, ion-dipole interaction, co-ordination bonds, acidbase reactions, charge transfer, and van der Waals forces. The interlayer cations can be exchanged by various types of organics cations. Grafting reactions, i.e., forming covalent bonds between reactive surface groups and organic species, are important steps to enhance the hydrophobicity of the surface of many clay mineral particles. Only the 2:1 clay minerals that provide the silanol and aluminol groups on the edge surface react with organic agents by grafting reactions. The organoclays are generally prepared in solution by cation exchange or solid-state reactions (Gopakumar et al., 2002; Lepoittevin et al., 2002; Xu et al., 2001).

Cation exchange has been used for five decades (Beall and Goss, 2004). The technique consists in the exchange of interlayer cations of the clay mineral with quaternary alkylammonium cations in aqueous solution. In some cases other kinds of organic compounds have been used.

Examples of preparation of organophilic clays under different process conditions can be found elsewhere (Gorassi et al., 2003; Hongping et al., 2004; Kozak and Domka, 2004; Majdan et al., 2005; Moraru, 2001; Xi et al., 2004; Zhu et al., 2005). 
The present work has focused on the detailed study of organically modified montmorillonite, obtained by cation exchange from natural montmorillonite. The adsorption properties were tested with gasoline, diesel, kerosene and lubricating oil, and its swelling ability to promote separation of oil-water emulsions was examined.

\section{EXPERIMENTAL}

\subsection{Materials}

A green clay, provided by Dolomil (Brazil), was used during the preparation of the organoclays. The sample was sieved according to the Brazilian ABNT standard № $200(0.074 \mathrm{~mm})$. The ammonium quaternary salt (alkyl-dimethyl-benzyl ammonium chloride, Dodigen), purchased from Clariant, was used as surfactant. Its general structure is $[(\mathrm{CH} 3) 2(\mathrm{CH} 2 \mathrm{C} 6 \mathrm{H} 5) \mathrm{R} \mathrm{N}+] \mathrm{Cl}-$,comprising a mixture of structures in the following composition, according to the nature of the R group: $2 \%$ C10; 50 \% C12; $24 \%$ C14; 13 \% C18; 11 \% C16.

\subsection{Preparation of the Samples}

The method used involves cation exchange reactions, and was carried out in order to obtain the organoclays. It is based on a conventional method, reported by Valenzuela-Diaz (1994), which initially involves the dispersion of the clay (4 $\%$ in weight) in distilled water under agitation for 20 minutes. The sample is then allowed to settle for 24 hours, after which $9.8 \mathrm{~g}$ of the ammonium quaternary salt are added to the dispersion, which is stirred for a further 20 minutes. After another 24-hour settling period, the solid sediments are filtered out, dried at $(60 \pm 5){ }^{\circ} \mathrm{C}$ for 48 hours and sieved in an ABNT $\mathrm{N}^{\circ} 200(0.074 \mathrm{~mm})$ sieve. The methodology used in this work has been adapted from the conventional one, by reducing the preparation time to one day, since the steps comprising the 24-hour settling periods, namely that after the clay dispersion in water and that after the addition of $9.8 \mathrm{~g}$ of ammonium quaternary salt, are not performed. This second procedure was called the "direct method", and was based on the works by Pereira (2003).

\subsection{Characterization of the Samples}

$X$-Ray Diffraction (XRD): the powder method was used, whereby the samples were sieved in an ABNT № $200(0.074 \mathrm{~mm})$ sieve and then placed in an aluminum sample door for X-ray diffraction, using a Shimadzu XRD 6000 equipment. Operational details of the technique have been set as follows: Copper $\mathrm{K} \alpha$ radiation at $40 \mathrm{KV} / 30 \mathrm{~mA}$, with a goniometer velocity of $2 \% \mathrm{~min}$ and a step of $0.02^{\circ}$ in the range of $2 \theta$ scanning from $2 \circ$ to $45^{\circ}$. The only $d$-spacings of interest in the $X$-ray patterns were the basal spacing along the $c$ axis.

Infrared Spectroscopy (IR): the organoclays obtained by two different methods were sieved (ABNT № 200) and then submitted to a physical treatment as in the $\mathrm{KBr}$ method, which consists in mixing $0.007 \mathrm{~g}$ of the sample and $0.1 \mathrm{~g}$ of $\mathrm{KBr}$, grinding and pressing the solid mixture to 5 ton during $30 \mathrm{~s}$ in order to form a pastille that allows the passage of light. The characterization was realized using an infrared spectrophotometer AVATAR TM 360 FT-IR E.S.P., with wavelengths ranging between 4000 to $400 \mathrm{~cm}^{-1}$, increments of $500 \mathrm{~cm}^{-1}$ and resolution of $4 \mathrm{~cm}^{-1}$.

Differential Thermal and Thermogravimetric Analyses (DTA / TG): Thermal analysis was performed using TA instruments operating at a ramp of $10{ }^{\circ} \mathrm{C} / \mathrm{min}$ from room temperature up to $1000^{\circ} \mathrm{C}$.

The Foster Swelling Test: This technique is employed to carry out studies on the compatibility of specific organoclays and clays that were obtained after the modification with ammonium quaternary salt with some different organic liquids. This method was measured following a method based on the "Standard Test Method for Swell Index of Clay Mineral Component of Geosynthetic Clay Liners" (ASTM D 5890-95). The organic solvents for the study of the swelling phenomena were: gasoline (Petrobras), diesel oil (Petrobras), kerosene (Ares) and lubricating oil (Lubrax MG1). The test consisted in adding $1 \mathrm{~g}$ of the powder sample to $50 \mathrm{~mL}$ of solvent in a test tube. After 24 hours of rest, the reading of the clay column volume (swelling of the clay without agitation) was registered. Afterwards, the content of the test tub was stirred with a glass stick during 5 minutes and, after a further 24-hour settling period, a new reading of the clay column volume (swelling of the 
clay with agitation) was taken. The following parameters have been fixed for the interpretation of the test (Pereira et al., 2005): non-swelling (minor or equal to $2 \mathrm{~mL} / \mathrm{g}$ of clay), low swelling (between 3 and $5 \mathrm{~mL} / \mathrm{g}$ of clay), intermediate swelling (between 6 and $8 \mathrm{~mL} / \mathrm{g}$ of clay) and high swelling (more than $8 \mathrm{~mL} / \mathrm{g}$ of clay).

Adsorption Capacity: The gasoline (Petrobras), diesel (Petrobras), kerosene (Ares) and lubricating oil (Lubrax MG1) sorption capacity was measured following a method based on the "Standard Methods of Testing Sorbent Performance of Adsorbents" (ASTM F716-82 and ASTM F 726-99). In this method, the adsorbent sample is weighed (minimum $1 \mathrm{~g}$ ), and the exact value is recorded. The test cell is filled with an initial layer of test liquid. The adsorbent is placed in a basket (a 200mesh stainless steel basket), which is then lowered into the test cell. The adsorbent should be allowed to float freely within the test cell. After 15 minutes \pm 0.33 minute, the basket with the adsorbent is removed manually in a vertical direction and allowed to drain for 15 seconds \pm 3 seconds. A tared weighing support is placed under the adsorbent sample/mesh basket set to catch any additional drips and the entire system is weighed. All tests were conducted in duplicate with a minimum of two runs used for calculations. Based on the data obtained, the amount of adsorbed oil was calculated as a weight ratio of adsorbed oil to dry adsorbent. The adsorption capacity is then obtained with Equation 1, referring to the adsorption efficiency $\left(A_{d}\right)$ of the adsorbent tested, in percentage. In the equation, $P_{1}$ is the mass of material after adsorption and $P_{2}$ is the mass of dry adsorbent material, both in grams. The results of the adsorption capacity can also be reported in grams of solvent adsorbed per gram of clay.

$$
A_{d}=\left(\frac{P_{1}-P_{2}}{P_{2}}\right) * 100
$$

\subsection{Factorial experimental design}

A factorial design was proposed with three factors aiming to analyze the influence of initial oil concentration in aqueous solution $\left(C_{0}\right)$ on the separation of oil-water emulsions. The variables obtained from this study were: the total oil removal percentage (\%Rem) and the capacity of oil removal at equilibrium.
Table 1. $2^{2}$-Factorial experimental design.

\begin{tabular}{ccc}
\hline Assay & $C_{0}$ & $A$ \\
\hline 1 & - & - \\
2 & + & - \\
3 & - & + \\
4 & + & + \\
5 & 0 & 0 \\
6 & 0 & 0 \\
7 & 0 & 0 \\
\hline
\end{tabular}

The design included four assays at the coordinated points $\left(x_{i}= \pm 1\right)$ for both factors (corresponding to the factorial part), and three repeated tests at the central point $\left(x_{i}=0\right)$, corresponding to average values between the variables' lower and upper levels, accounting for eleven tests. Repetitions at the central point have the purpose of supplying a value of pure error and stabilizing the variance of forecasted results.

The analysis of variance was originated by the ANOVA with software Minitab 15.0 and was used as a basis for the interpretation of results obtained experimentally. The values for levels $(+)$ and $(-)$ are shown in Table 1 , where $C_{0}$ is the initial concentration of the oil solution (water/oil emulsion) and $A$ refers to the mechanical agitation. These levels are quantitatively indicated in Section 2.5 .

\subsection{Finite bath tests}

The experiments were performed simultaneously, by mixing $0.5 \mathrm{~g}$ of clay with a 50 $\mathrm{mL}$ water/oil emulsion (LUBRAX MG1) with concentrations of 100,300 and $500 \mathrm{mg} / \mathrm{L}$. These numbers refer to the content of oil in each sample. The mixture (oil/water emulsion + clay) was kept under mechanical agitation from 100 to $200 \mathrm{rpm}$ for 6 hours to ensure the balance of the system (Curbelo, 2002). Similarly, the process without agitation was carried out.

Oil-water separation test: The concentration of oil present in the aqueous phase was determined by analysis of absorbance using a UV-visible spectrophotometer. Initially, a calibration curve of 
absorbance versus concentration was constructed using previously defined concentrations of oil. These concentrations ranged from 0 to $100 \mathrm{ppm}$ and the solvent used for extraction was chloroform, showing a response (significant peak) at a wavelength of $262 \mathrm{~nm}$ for the analyzed samples. The absorbance at this wavelength is commonly used to estimate the concentration of oil in water samples (Greenberg et al., 1985; Henderson et al., 1999) and also in produced water. Bands of aromatic $\mathrm{CH}$ in the media are measured at this wavelength. Based on this, the absorbance was measured at this wavelength. This implementation procedure was designed to normalize the determination of oil and grease contents.

Determination of the amount of oil: The total oil removal percentage (\%Rem) and the capacity of oil removal at equilibrium ( $q_{\text {eq }}$ in $\mathrm{mg}$ of oil/g of adsorbent) can be obtained with Equations 2 and 3, respectively:

$$
\begin{aligned}
& \% \operatorname{Re} m=\left(\frac{C_{0}-C_{\mathrm{eq}}}{C_{0}}\right) \times 100 \\
& q_{e q}=\frac{V}{m}\left(C_{0}-C_{e q}\right)
\end{aligned}
$$

where: $C_{0}$ is the initial concentration of the oil solution (water/oil emulsion), in $\mathrm{mg} / \mathrm{L} ; \mathrm{C}_{\text {eq }}$ is the final concentration of the solution (water/oil emulsion), in $\mathrm{mg} / \mathrm{L} ; \mathrm{V}$ is the volume of adsorbate, in $\mathrm{mL}$; and $\mathrm{m}$ is the mass of adsorbent, in $\mathrm{g}$.

It is possible to determine the amount of adsorbed oil, expressed in $\mathrm{mg}$ of aqueous solution per gram of solid adsorbent, by means of a relatively simple calculation, as in Equation 3.

\section{RESULTS AND DISCUSSION}

Figures 1 and 2 show typical X-ray diffractograms of the untreated clay and the green clay treated with the ammonium quaternary salt (Dodigen). From the XRD patterns shown, it has been verified that the interlamellar distances (d001) of the untreated (non-modified

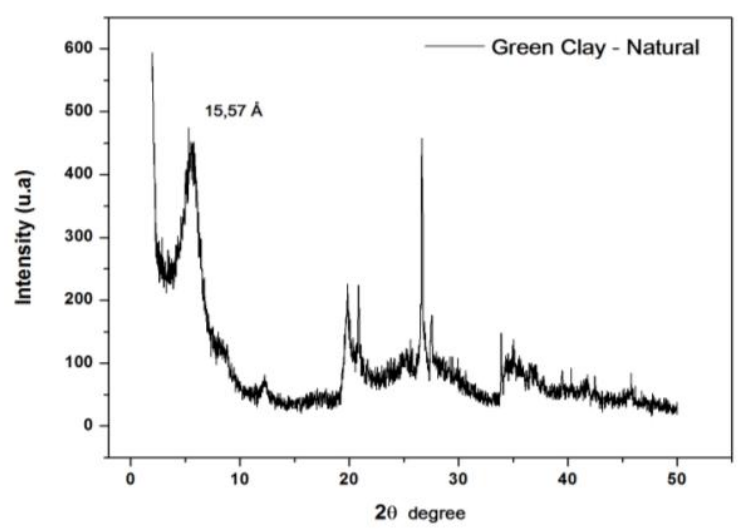

Figure 1. X-ray patterns of the untreated green clay.

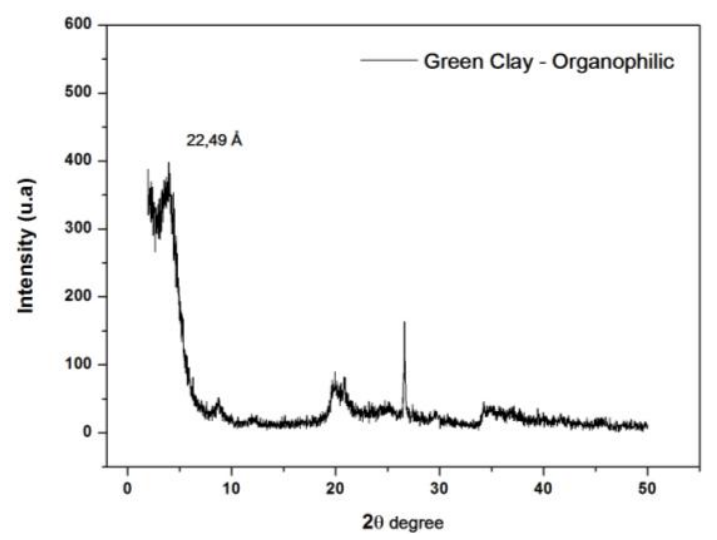

Figure 2. X-ray patterns of the green clay treated with Dodigen.

montmorillonite) and treated clays are $1.516 \mathrm{~nm}$ and $2.247 \mathrm{~nm}$, respectively. These values are consistent with results reported earlier on the characterization of Brasgel Clay. The results of basal spacing $\mathrm{d}(001)$ are $13.29 \AA$ for natural sample and $21.01 \AA$ for the organoclay (Rodrigues et al., 2010).

When the modifying substance is not able to penetrate into the interlayer space, the value of $\mathrm{d}_{001}$ does not change. Such a situation could be observed, for example when attempting to use fatty acids (stearic or 9-octadecenoic acids) in the modification procedure. The fatty acids molecules covered only the surface of montmorillonite and did not penetrate into the interlayer space (Khalil and Abdelhakim, 2002). 
In Figures 3 and 4, infrared spectra are shown for untreated green clay and green clay treated with Dodigen. It can be observed that the $3626 \mathrm{~cm}^{-}$ ${ }^{1}$ band is resolved in the untreated sample, due to the presence of the hydroxyl structural group in the clay. The wavenumber of $1651 \mathrm{~cm}^{-1}$ indicates the presence of adsorbed water. In the Figures, it is possible to detect vibrations of the $\mathrm{Si}-\mathrm{O}$ group $\left(1045 \mathrm{~cm}^{-1}\right)$ and octahedral layers (between 523 and $525 \mathrm{~cm}^{-1}$ ) for both samples.

The presence of $\mathrm{CH}_{2}$ groups was also verified in the treated clay, as indicated by bands within the wavenumber range from 2918 to $2848 \mathrm{~cm}^{-1}$. The asymmetric angular deformation of the $\mathrm{CH}_{3}$ groups occurs at about $1459 \mathrm{~cm}^{-1}$. The presence of $\mathrm{CH}_{2}$ and $\mathrm{CH}_{3}$ groups in the infrared spectrum of the treated samples is a good evidence of the intercalation of the ammonium quaternary cation of the surfactant within the interlamellar spaces of the sample (Hermosin and Conejo, 1993; Kozak and Domka, 2004).

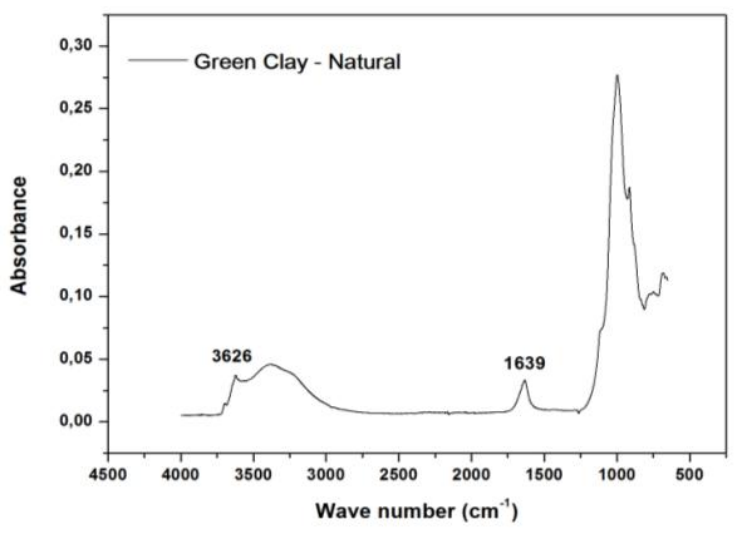

Figure 3. Infrared spectra of the untreated green clay.

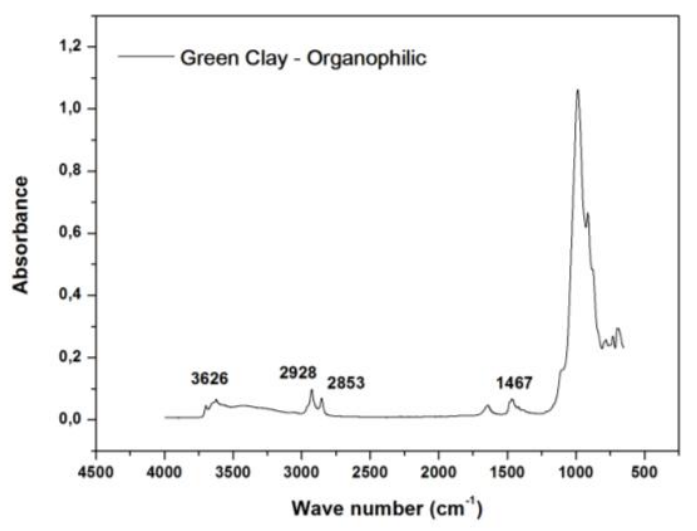

Figure 4. Infrared spectra of the green clay treated with Dodigen.

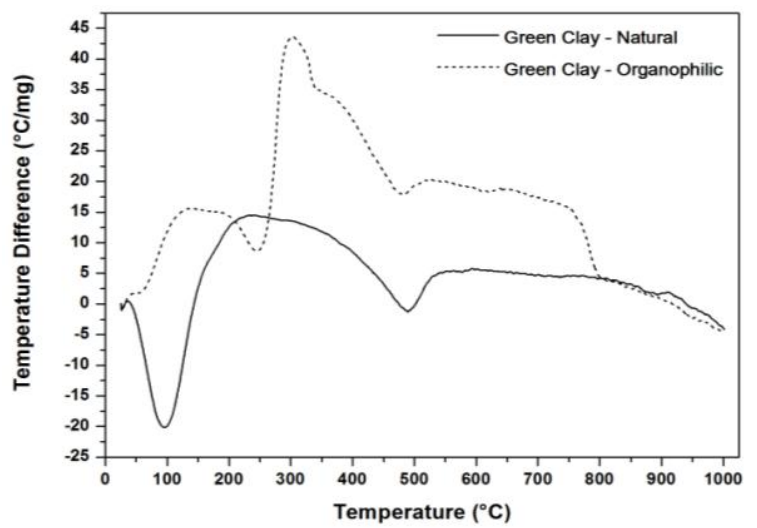

Figure 5. Thermal analyses of the green clay: untreated and treated with Dodigen.

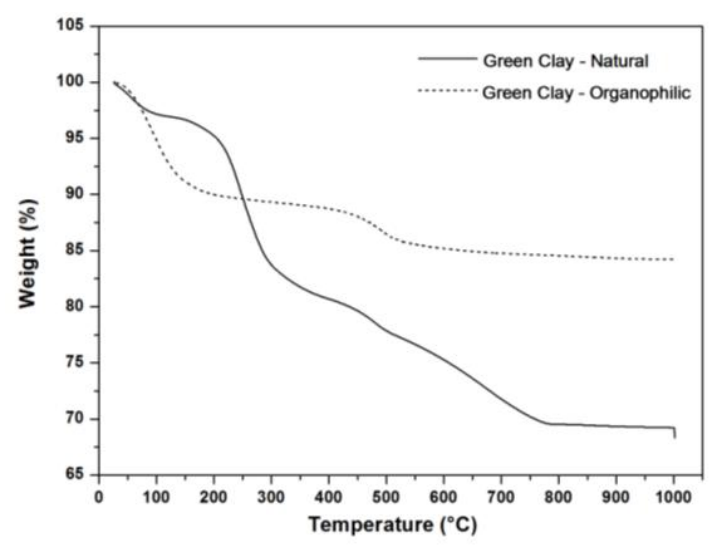

Figure 6. Thermogravimetric analysis of the green clay: untreated and treated with Dodigen.

The results of the differential thermal analysis are shown in Figure 5 for both natural and treated samples. For the natural, untreated sample, an endothermic peak is observed between $34{ }^{\circ} \mathrm{C}$ and $140{ }^{\circ} \mathrm{C}$, with the loss of free water. This change is due to water being intercalated and adsorbed by clay minerals. Another endothermic peak has also been detected between $250^{\circ} \mathrm{C}$ and $400{ }^{\circ} \mathrm{C}$, which has been attributed to elimination of water molecules that were coordinated with the cations, thereby causing the formation of the cation basis. As for the green organophilic clay, an exothermic peak, attributed to the decomposition of salt, is seen between $272{ }^{\circ} \mathrm{C}$ and $330^{\circ} \mathrm{C}$. Interestingly, its curve exhibits endo-exo peaks in the range of 410 ${ }^{\circ} \mathrm{C}$ to $800{ }^{\circ} \mathrm{C}$, referring to dehydroxylation of the organoclay and secondary combustion of carbonaceous residues from prior burning (Sora et al., 2005). 
The thermogravimetric analyses (TG) for the untreated green clay and gray organoclay are shown in Figure 6. For the untreated clay, the total weight loss of adsorption water was $16.59 \%$; for the green clay treated with Dodigen, this value was as high as $30.37 \%$.

The study on the adsorption of organic compounds was based on the "Standard Methods of Testing Sorbent Performance of Adsorbents" (ASTM F716-82 and ASTM F 726-99). The experimental results of the adsorption capacity of natural green clay and green organophilic clay are shown in Figure 7. The order of organoclay adsorption capacity was gasoline $>$ diesel $>$ lubricating oil > kerosene.

From these results, it is possible to suggest that organophilic clays have better adsorption capacity in all solvents when compared with natural green clay. The order of natural clay adsorption capacity was kerosene $>$ diesel $>$ lubricating oil $>$ gasoline. The adsorption values were between 0.92 to $1.98 \mathrm{~g}$ hydrocarbon/g natural clay. The extent of adsorption of gasoline by the organoclay was approximately equal to six times its weight, and that of lubricating oil was equal to about 3.5 times the weight of adsorbent. This organoclay may then be used as adsorbent material for hydrocarbons.

Table 2 shows the results of the Foster swelling tests performed with the green clay treated with Dodigen. In these assays, all samples were allowed to interact with different organic solvents. It was noticed that the treated sample presented a high swelling capacity (with agitation and without agitation) when tested in gasoline. On the other

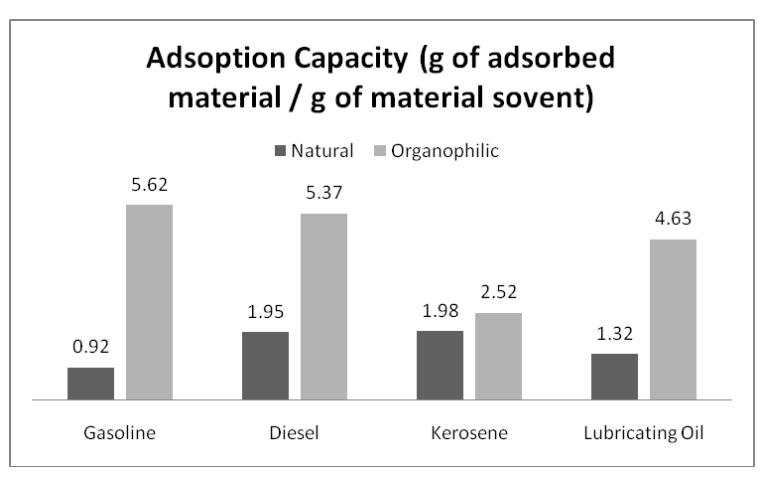

Figure 7. Adsorption capacity in the presence of gasoline, diesel, kerosene or lubricating oil.
Table 2. Results of the Foster swelling tests performed in different organic solvents, without and with agitation, for the green clay treated with Dodigen.

\begin{tabular}{ccccc}
\hline Solvents & Gasoline & Diesel & Kerosene & $\begin{array}{c}\text { Lubricating } \\
\text { oil }\end{array}$ \\
\hline $\begin{array}{c}\text { No } \\
\text { agitation }\end{array}$ & 9.0 & 8.0 & 3.0 & $\begin{array}{c}\text { Not } \\
\text { detected }\end{array}$ \\
Agitation & 13.0 & 10.5 & 4.0 & $\begin{array}{c}\text { Not } \\
\text { detected }\end{array}$ \\
\hline
\end{tabular}

hand, when inserted in diesel oil without agitation, the treated samples presented intermediate swelling capacity, but when the assay was performed under agitation, the swelling capacity was high. When inserted in kerosene, the samples presented low swelling, both without and with agitation. No swelling was observed with the lubricating oil. This behavior can be possibly explained because there was no change in the column volume.

Overall, the results of Foster swelling test with agitation showed better results than without agitation. The data clearly illustrate the hydrophobicity of the green organoclay, showing that the organoclay has a great potential in the oil/water separation process. This effect is partially explained by the chemical structure of gasoline, which is a liquid fuel obtained by refining oil, consisting essentially of a mixture of light hydrocarbons (Gamal et al., 2005; IBP, 2009).

The results obtained for the percentage of oil removal and the removal capacity are presented in Table 3. This study was carried out by means of a $2^{2}$-factorial planning for the system used to remove oil from synthetic effluents with clays treated with Dodigen. All abbreviations shown in Table 2 have been explained in previous sections. In particular, $C_{0 \text {-calc }}$ refers to the theoretical initial concentration of oil in the emulsion and $C_{0 \text {-exp }}$ is the actual initial concentration.

The results shown in the "oil" (ppm) column are calculated as reported in section 2.5. Assay 2 provided the best result, reaching a total oil removal percentage as high as $95.03 \%$. It was also 
Table 3. Results of the $2^{2}$-Factorial experimental design for green clay treated with Dodigen.

\begin{tabular}{ccccccc}
\hline Assay & $C_{0 \text {-calc }} /(\mathrm{mg} / \mathrm{L})$ & $C_{0 \text {-exp }} /(\mathrm{mg} / \mathrm{L})$ & $A / \mathrm{rpm}$ & Oil $/(\mathrm{mg} / \mathrm{L})$ & $\% R e m$ & $q_{\mathrm{eq}} /(\mathrm{mg} / \mathrm{g})$ \\
\hline 1 & 100 & 98 & 0 & 33.82 & 65.49 & 6.42 \\
2 & 500 & 512 & 0 & 25.44 & 95.03 & 48.65 \\
3 & 500 & 512 & 200 & 26.72 & 94.78 & 48.53 \\
4 & 100 & 98 & 200 & 30.27 & 69.11 & 6.77 \\
5 & 300 & 368 & 100 & 27.77 & 92.45 & 34.02 \\
6 & 300 & 368 & 100 & 26.29 & 92.86 & 34.17 \\
7 & 300 & 368 & 100 & 26.54 & 92.79 & 34.14 \\
\hline
\end{tabular}

observed that, in terms of the capacity of oil removal at equilibrium $\left(q_{\text {eq }}\right)$, the best results were obtained in assays carried out under higher oil concentrations, the best result being again that of assay 2, with the removal of $48.65 \mathrm{mg}$ of oil for every gram of green clay.

Montmorillonite, hectorite and saponite are the most commonly used layered silicates. These types of clay are characterized by a moderately negative surface charge (known as the cation exchange capacity, CEC, and expressed in miliequivalent/100 $\mathrm{g}$, or meq/100 g). The charge of the layer is not locally constant as it varies from layer to layer, and must rather be considered as an average value over the whole crystal. Proportionally, even if a small part of the charge balancing cations is located on the external crystallite surface, the majority of these exchangeable cations is located inside the galleries. When the hydrated cations are ionexchanged with organic cations such as more bulky alkylammonium groups, it usually results in a larger interlayer spacing (Lagaly, 1986). Organoclays consist of bentonite that has been modified with quaternary amine cations. The positively charged nitrogen cation exchanges with sodium and calcium ions on the clay surface (Mortland, 1970). This exchange provides an organophilic material, that does not swell in water, but swells in hydrocarbon fluids such as kerosene, diesel fuel and similar mixtures. The quaternary amine chains extend away from the clay surface into the water
(Mortland, 1986). The amine chain then becomes neutral because the cation is attached to the clay surface, rendering the entire system into a nonionic organoclay. This chemical modification allows it to function as a non-ionic surfactant which removes oil and other organic compounds of low polarity via partition phenomena (Smith and Jaffe, 1994).

\section{CONCLUSIONS}

In this study, the removal of oil was investigated using clay treated with an ammonium quaternary salt (alkyl-dimethyl-benzyl ammonium chloride, or Dodigen). The changes in the basal spacing indicated in the XRD patterns suggested a formation of bilayer of quaternary ammonium chlorides in the interlayer space. The presence of the quaternary ammonium chlorides in the interlayer space was also confirmed independently by FTIR, and was manifested by the appearance of bands corresponding to $\mathrm{C}-\mathrm{C}$ stretching and $\mathrm{C}-\mathrm{H}$ vibrations. The Foster swelling test results indicated that the affinity of Dodigen with the treated clay in all organic solvents tested (gasoline, diesel, kerosene and lubricating oil) was high, both without and with agitation. Total oil removal percentages as high as $95.03 \%$ could be obtained, when the initial solution (water/oil emulsion) concentration was used on its higher level (500 
$\mathrm{mg} / \mathrm{L}$ ) and without agitation. It was also observed that, with regards to the capacity of oil removal at equilibrium, the best results were obtained in tests performed with higher $(500 \mathrm{mg} / \mathrm{L})$ concentration, and a maximum of $48.65 \mathrm{mg}$ of oil could be removed for every gram of clay.

\section{ACKNOWLEDGMENTS}

The authors gratefully acknowledge CAPES, Dolomil, Clariant and Petrobras.

\section{REFERENCES}

Ahmadun, F.R.; Pendashteh, A.; Abdullah, L.C.; Biak, D.R.A.; Madaeni, S.S.; Abidin, Z.Z. Review of technologies for oil and gas produced water treatment. Journal of Hazardous Materials, v.170, p. 530-551, 2009.doi:10.1016/i.jhazmat.2009.05.044

ASTM - American Society for Testing and Materials. 1999. Standard Methods of Testing Sorbent Performance of Adsorbents. ASTM Designation F726-99.

ASTM - American Society for Testing and Materials. 1982. Standard Methods of Testing Sorbent Performance of Adsorbents. ASTM Designation F716 -82 (Reapproved 1993).

ASTM - American Society for Testing and Materials. 1995. Standard Test Methods For Swell Index of Clay Mineral Component of Geosynthetic Clay Liners - ASTM Designation D 5890-95.

Bandosz, T.J. (Ed.), Activated Carbon Surfaces in Environmental Remediation, Elsevier Science Publishing, Amsterdam, 2006. 588 p.

Beall, G.W.; Goss, M. Self-assembly of organic molecules on montmorillonite. Applied Clay Science, v. 27, p. 179-186, 2004. doi:10.1016/j.clay.2004.06.006

Bergaya F.; Lagaly, G. Surface modification of clay minerals. Applied Clay Science, v. 19, p. 1-3, 2001. doi:10.1016/S0169-1317(01)00063-1

Boyd, S.A.; Mortland, M.M.; Chiou, C.T. Sorption characteristic of organic compounds on hexadecyltrimethylammonium-smectite. Soil Sci. Soc. Am. J., v. 52, p. 652-657, 1988. doi:10.2136/sssaj1988.03615995005200030010x
Boyd, S.A.; Shaobai, S.; Lee, J.F.; Mortland, M.M. Pentachlorophenol sorption by organo-clays. Clays Clay Miner., v.36, p. 125-130, 1988. doi:10.1346/CCMN.1988.0360204

Chaiko, D. Process for the preparation of organoclays, PCT Int. Appl., WO 2002044101, 2002.

CONAMA - Conselho Nacional do Meio Ambiente, Resolução 393/2007 (in Portuguese).

Curbelo, F.D.S. Estudo da remoção de óleo em águas produzidas na indústria de petróleo, por adsorção em coluna utilizando a vermiculita expandida e hidrofobizada. 102f. Dissertação de Mestrado, Programa de Pós-Graduação em Engenharia Quimica, Universidade Federal do Rio Grande do Norte, 2002. (in Portuguese).

Flanigen, E.M.; Bennett, J.M.; Grose, R.W.; Cohen, J.P.; Patton, R.L.; Kirchner, R.M.; Smith, J.V. Silicalite, a new hydrophobic crystalline silica molecular sieve. Nature, v.271, p. 512-516, 1978. doi:10.1038/271512a0

Gamal, M. E.; Mohamed, A.M.O.; Zekri, A.Y. Effect of asphaltene, carbonate, and clay mineral contents on water cut determination in water-oil emulsions. Journal of Petroleum Science and Engineering, v. 46 p. 209-224, 2005. doi:10.1016/i.petrol.2004.11.002

Gopakumar, T.G.; Lee, J.A., Kontopoulo, M.; Parent, J.S. Influence of clay exfoliation on the physical properties of montmorillonite/polyethylene composites. Polymer, v.43, p. 5483-5491, 2002. doi:10.1016/S0032-3861(02)00403-2

Gorassi, G.; Tortora, M.; Vittoria, V.; Kaempfer, D.; Mülhaupt, R. Transport properties of organic vapor in nanocomposites of organophilic layered silicate and syndiotactic polypropylene. Polymer, v.44, p. 3679-3685, 2003. doi:10.1016/S00323861(03)00284-2

Greenberg, A.E.; Trussell, R.R.; Clesceri, L.S. (Ed.) Standard methods for the examination of water and wastewater. American Public Health Association Publications, 16th Edition, Washington, DC. p. 498-499. 1985. 
Hermosin, M.C.; Conejo, J. Binding mechanism of 2,4- dichlorophenoxyacetic acid by organoclays. Journal of Environmental Quality, 22, p. 325-331, 1993.

\section{doi:10.2134/jeq1993.00472425002200020013x}

Henderson, S.B.; Grigson, S.J.W.; Johnson, P.E.; Roddie, B.D. Potential impact of production chemicals on the toxicity of reduced water discharges from North Sea oil platforms. Marine pollution Bulletin, v. 38, no 12, p. 1141-1151, 1999. doi:10.1016/S0025-326X(99)00144-7

Hongping, H.; Ray, F.; Jianxi, Z. Infrared study of HDTMA $^{+}$intercalated montmorillonite. Spectrochim. Acta, Part A 60, p. 2853-2859, 2004. doi:10.1016/j.saa.2003.09.028

IBP - Instituto Brasileiro de Petróleo, Gás e Biocombustíveis. Avalaible at http://www.ibp.org.br. Accessed on October $23^{\text {rd }}$, 2009. (in Portuguese).

Khalil, H.S.A.; Abdelhakim, A.A. Adsorption studies of fatty acids on montmorillonite-based filler clay. Journal of Applied Polymer Science, v.86, p. 2574-2580, 2002. doi:10.1002/app.11184

Kim, J.H.; Shin, W.S.; Kim, Y.H.; Choi, S.J.; Jeon, Y.W.; Song, D.I. Sequential sorption and desorption of chlorinated phenols in organoclays. Water Science Technology, v.47, p. 59-64, 2003.

Kozak, M.; Domka, L. Adsorption of the quaternary ammonium salts on montmorillonite. Journal of Physics and Chemistry of Solids, v. 65, p. 441-445, 2004. doi:10.1016/i.jpcs.2003.09.015

Lagaly, G. Clay-organic interactions. Philos. Trans. R. Soc. Lond. v. 311 A, p. 315-332, 1984.

Lagaly, G. Interactions of alkylamines with different types of layered compounds, Solid State Ionics, v.22, p. 43-51, 1986. doi:10.1016/01672738(86)90057-3

Lepoittevin, B.; Devalckenaere, M.; Pantoustier, N.; Alexandre, M.; Kubies, D.; Calberg, C.; Jerome, R.; Dubois, P. Poly(e-caprolactone)/clay nanocomposites prepared by melt intercalation: mechanical, thermal and rheological properties. Polymer, v.43, n ${ }^{0} 14$, p. 4017-4023, 2002. doi:10.1016/S0032-3861(02)00229-X
Majdan, M.; Maryuk, O.; Pikus, S.; Olszewska, E.; Kwiathowski, R.; Skrzypek, H. Equilibrium, FTIR, scanning electron microscopy and small wide angle $X$-ray scattering studies of chromates adsorption on modified bentonite. J. Mol. Struct, v.70, p. 203211, 2005. doi:10.1016/i.molstruc.2005.01.044

Moraru, V.N.M. Structure formation of alkylammonium montmorillonites in organic media. Applied Clay Science, v.19, p. 11-26, 2001. doi:10.1016/S0169-1317(01)00053-9

Mortland, M.M. Clay-organic complexes and interactions. Adv Agronomy, v.22, p.75-117, 1970. doi:10.1016/S0065-2113(08)60266-7

Mortland, M.M.; Shaobai, S.; Boyd, S.A. Clayorganic complexes as adsorbents for phenols and chlorophenols. Clays and Clay Minerals, v.34, n.5, p. 581-585, 1986.

doi:10.1346/CCMN.1986.0340512

Pereira, K.R.O. Ativação ácida e preparação de argilas organofílicas partindo-se de argila esmectítica proveniente do Estado da Paraíba. 95f. Dissertação de Mestrado. Programa de PósGraduação em Engenharia Química, Universidade Federal de Campina Grande, 2003. (in Portuguese).

Pereira, K.R.O.; Hanna, R.A.; Vianna, M.M.G.R.; Pinto. C.A.R.; Rodrigues, M.G.F.; Valenzuela- Diaz, F.R. Brazilian organoclays as nanostructured sorbents of petroleum-derived hydrocarbons. Materials Research, v. 8, p. 77-80, 2005. doi:10.1590/S1516-14392005000100014

Ray, S.S.; Okamoto, M. Polymer/layered silicate nanocomposites: a review from preparation to processing. Progress in Polymer Science, v. 28, p. 1539-1641, 2003.

doi:10.1016/j.progpolymsci.2003.08.002

Rodrigues, S.C.G.; Queiroz, M.B.; Pereira, K.R.O.; Rodrigues, M.G.F.; Valenzuela- Diaz, F.R. Comparative study of organophilic clays to be used in the gas \& petrol industry. Materials Science Forum, v. 660, p. 1037-1042, 2010. doi:10.4028/www.scientific.net/MSF.660-661.1037

Shannon, M.A.; Semiat, R. Advancing materials and technologies for water purification. MRS Bull., v.33, p. 9-15, 2008. doi:10.1557/mrs2008.8 
Sheintuch, M.; Matatov-Meytal, Y. Comparison of catalytic processes with other regeneration methods of activated carbon. Catalysis Today, v. 53, p. 73-80, 1999. doi:10.1016/S09205861(99)00104-2

Smith, J.A.; Jaffe, P.R. Benzene Transport through a landfill liner containing organophilic bentonite. Journal of Environmental Engineering, v. $120, \quad$ p. $1559-1977,1994$. doi:10.1061/(ASCE)0733-9372(1994)120:6(1559)

Soule, N.M.; Burns, S.E. Effects of organic cation structure on behavior of organobentonites, Journal of Geotechnical and Geoenvironmental Engineering, v. 127, p. 363-370, 2001. doi:10.1061/(ASCE)1090-0241(2001)127:4(363)

Sora, I.N.; Zampori, L.; Pelosato, R.; Botta, D.; Dotelli, G.; Vitelli, M. Matrix optimization for hazardous organic waste sorption, Applied Clay Science, v. 28, p. 43-54, 2005. doi:10.1016/j.clay.2004.01.015

Sutherland, J.; Adams, C.; Kekobad, J. Treatment of MTBE by air stripping, carbon adsorption, and advanced oxidation: technical and economic comparison for five groundwaters. Water Research, v.38, p. 193-205, 2004. doi:10.1016/j.watres.2003.09.008
Valenzuela-Diaz, F.R. Preparação a nível de laboratório de algumas argilas esmectíticas organofílicas. 256f. Tese de Doutorado. Programa de Pos-Graduação em Engenharia Quimica, Escola Politecnica da Universidade de Sao Paulo, 1994. (in Portuguese).

Xi, Y.; Ding, Z.; He, H.; Frost, R.L. Structure of organoclays-an $X$-ray diffraction and thermogravimetric analysis study. Journal of Colloid and Interface Science, v.277, p. 116-20, 2004. doi:10.1016/i.jcis.2004.04.053

Xu, R.; Manias, E.; Synder, A.J.; Runt. J. New biomedical poly(urethane urea)-layered silicate nanocomposites. Macromolecules, v.34, p.337339, 2001. doi:10.1021/ma0013657

Xu, S.; Sheng, G.; Boyd, S.A. Use of organoclays in pollution abatement, Advanced Agronomy, v. 59 , p. 25-62, 1997. doi:10.1016/S00652113(08)60052-8

Yariv, S.; Cross, H. Organo-clay complexes and interaction. Nova York, Marcel Dekker Inc., 2002, $688 p$.

Zhu, J.; He, H.; Zhu, L.; Wen, X.; Deng, F. Characterization of organic phases in the interlayer of montmorillonite using FTIR and $13 C$ NMR. Journal of Colloid and Interface Science, v.286, p. 239-244, 2005. doi:10.1016/j.jcis.2004.12.048 